\title{
THE SMALL TOWN IN RURAL AREAS AS AN UNDERRESEARCHED TYPE OF SETTLEMENT. EDITORS' INTRODUCTION TO THE SPECIAL ISSUE
}

\author{
Annett Steinführer ${ }^{1}$, Antonín Vaishar², Jana Zapletalováa
}

Received 1 December 2016; Accepted 6 December 2016

\section{Small towns in rural areas: a neglected yet relevant research subject}

The idea of an urban-rural continuum - rather than a dichotomous understanding of city versus countryside - is widely accepted and has a long tradition in both rural and urban studies (for an early account of the then "folk-urban continuum": Miner, 1952). Yet, this consensus is in sharp contrast with the scientific landscape where a strong urban-rural dichotomy prevails. While urban studies predominantly deal with cities and metropolises, rural geography and sociology tend to focus on villages in their settlement studies. Therefore, while the poles of the settlement structure have been fairly well explored, smaller towns are neglected structurally by both disciplines (Vaishar and Zapletalová, 2009; Steinführer, 2016). In comparison with the bulk of knowledge about cities and ruralities, respectively, there is fairly little systematic research about urban life in small(er) towns or, as Bell and Jayne (2009, p. 690) called it, about "small urbanity". In handbooks of urban studies, for example, urbanity beyond metropolises is not a topic to which specific attention is paid. When taken into consideration by urban scholars at all (rarely), small towns tend to be treated as a specific type of urban settlement to which concepts and theories developed for and in cities are applied (e.g., Hannemann, 2004). Yet, this transfer remains a one-way street, as the existing small-town research does not seem to have contributed to genuine topics of urban research such as socio-spatial differentiation, social exclusion, or urban governance. Within rural studies, there is an ambiguous relationship to small towns: on the one hand, they are considered urban (and, thus, not rural) when, for example, investigating the service functions for their rural "hinterland" (e.g., Powe and Shaw, 2004). On the other hand, however, traditional concepts of rurality are applied and empirically analysed. This holds true, in particular, for the concepts of community and social capital. Strong mutual and personal bonds, considered a specific feature of this type of human settlement, are a major topic of small-town research (e.g., Mattson, 1997, Besser, 2009).

A picture of non-knowledge - particularly in comparison with the bulk of studies on cities and metropolitan regions - does, however, prevail. The structural neglect of small towns by the social sciences is all the more astonishing as Europe is characterised by a dense network of small towns. Many of them are parts of metropolitan areas and often closely intertwined with a city's

\footnotetext{
${ }^{1}$ Dr. Annett Steinführer, Institute of Rural Studies, Johann Heinrich von Thünen Institute - Federal Research Institute for Rural Areas, Forestry and Fisheries, Bundesallee 50, 38116 Braunschweig, Germany; e-mail: annett.steinfuehrer@thuenen.de

2 Doc. RNDr. Antonín Vaishar, CSc., Department of Applied and Landscape Ecology, Faculty of AgriScience, Mendel University in Brno, Zemědělská 1, 61300 Brno, Czechia; e-mail: antonin.vaishar@mendelu.cz

${ }^{3}$ RNDr. Jana Zapletalová, CSc., Department of Environmental Geography, Institute of Geonics, Czech Academy of Sciences, v.v.i. Ostrava, Drobného 28, 60200 Brno, Czechia; e-mail: zapletalova@geonika.cz
} 
suburbia. Others are centres of rather peripheral rural areas with long distances to urban agglomerations. The latter type of small(er) towns represents a specific category of settlement that has for centuries been of crucial importance as economic, administrative, cultural and symbolic centres in a regional context. On a more aggregate level, small towns ease the burdens put on larger centres and can therefore be regarded as structural nodes in the settlement network. Moreover, in some peripheral rural regions, it is not the metropolis or city but rather the small town that is the normal expression of urban life (e.g., in north-eastern Germany, and in part already before 1945; Benke, 2001). In many parts of Central Europe, the small town is clearly distinguishable from its rural surroundings - manifested, for example, by traditional symbols of urbanity and urban power, such as the town hall or the town fortification. Yet, today, the historical heritage and its remains are not sufficient to maintain an attractive place for all generations and social groups. In the era of globalization and the increasing excessive importance of the agglomerations in economic, power-related and symbolic terms, many small towns and their surrounding regions face economic and population decline, infrastructure losses and symbolic disregard or even stigmatisation (Wirth et al., 2016, Bürk, 2013, Burdack, 2010, Knox and Mayer, 2012).

In this Special Issue the two poles of small-town development - towns within metropolitan areas and towns with a strong centrality function in peripheral rural areas - will be considered without leaving out other types. Before briefly introducing the assembled contributions, this introductory paper will discuss the question of small-town characteristics by starting with size in absolute and relative terms and approaching the topic in both contemporary and historical terms, and, subsequently, by focusing on structural features as applied in scholarly research.

\section{Numbers and words or: Does size matter?}

Defining the small town is far from easy. Two general approaches can be distinguished: one for practical use (e.g., statistical purposes) and the other scientific. For practical use, a definition has to be based on clear and easily available criteria like the number of inhabitants or legal definitions. Specific limits depend on characteristics of the particular settlement system. In lowlands which generally feature large rural settlements, the lower limit is, as a rule, higher in comparison with more dispersed settlements in highlands. The higher limit is connected with a level when urban settlements with basic urban functions differ from those with higher central functions. It is also connected with the historical development of the settlement network.

For scientific purposes the definition could and should be more complex and multi-criterial. When aiming at a sociological definition of the city in the 1930s, Louis Wirth claimed: "The characterization of a community as urban on the basis of size alone is obviously arbitrary" (Wirth, 1938, p. 4). Relating to the then US census criterion of 2,500 inhabitants for a settlement to be called "urban", he added: "The situation would be the same if the criterion were $4,000,8,000$, $10,000,25,000$ or 100,000 population, for although in the latter case we might feel that we were more nearly dealing with an urban aggregate than would be the case in communities of lesser size, no definition of urbanism can hope to be completely satisfying as long as numbers are regarded as the sole criterion" (Wirth, 1938, p. 4). It is well-known that Wirth eventually defined city "as a relatively large, dense, and permanent settlement of socially heterogeneous individuals" (ibid., p. 8).

About half a century before Wirth, urban statistics had come about as a new endeavour to categorise the new numbers of city dwellers and, as it was felt by the contemporaries, at the same time the new quality of urban life in the course of $19^{\text {th }}$ century's industrialisation and rapid urbanisation. In 1887, the first session of the International Statistical Institute (ISI) eventually defined three categories of settlement. Based on a decision already taken during the ISI founding meeting in 1885, the lowest limit was a population of 2,000. All settlements with fewer residents were called countryside (campagne). The upper boundary of 100,000 inhabitants was reserved for a newly denominated urban form: the cities (grandes villes). The settlements and social realities between these two poles were simply called towns (villes) (Körösi, 1887, p. 212). This was not considered a problem as the newly arising cities were - just as in the case of Wirth the focus of the statisticians. Until today, the in-between category remains more or less vague, signalled very often with the use of the collective term "small- and medium-sized towns". While 
for Wirth - and following him for most social scientists - size in a relational understanding was a decisive feature of the city, the statisticians chose (or rather had to choose) a clear size limit. Interestingly, until today the population number of 100,000 is used, for example in Germany, for distinguishing a town and a city (Großstadt), and this number is also relevant in other countries (e.g., in Poland).

Not every language has distinct terms for town and city. Historically, this is also true for German and Czech, the mother tongues of the editors of this Special Issue. But in both languages compounds developed that allow for making the quantitative difference obvious: In German, one distinguishes between Kleinstadt (small town) and Großstadt (big town or city), similarly in Czech between maloměsto and velkoměsto. Without being linguists, it is, however, noteworthy, that these words signal more than just "small" or "big town", as this would be expressed in another way, namely as kleine Stadt/malé město and große Stadt/velké město, respectively. Thus, the compounds also signal a qualitative difference and point to these types of settlements as specific categories. In a paper on composite words, the Czech linguist and Slavicist František Trávníček used exactly the examples of maloměsto and malé město to provide evidence for their slight difference as regards meaning. While velkoměsto (city) in his perception relates to "a great degree of cultural, political and societal life", maloměsto is bound to a "small, weak cultural life" (Trávníček, 1936, p. 24). The German-born Louis Wirth wrote his sociological conceptualisation in English applying the term "city". In German, he would for sure have made use of the word Großstadt, which as a term regularly used emerged in the very early $19^{\text {th }}$ century (DWB 9/1935, column 581). As for German, another interesting finding is that Kleinstadt according to the German Dictionary (DWB, which was originally founded by the brothers Grimm with the first volume being published in 1852) was a rather late neologism. It followed, rather than preceded, the adjective "small-town" (kleinstädtisch) that had developed in the $17^{\text {th }}$ century (DWB 11/1873, column 1131). Interestingly, already in the 1870 s kleinstädtisch is not referred to as a neutral term but rather directly bound to "narrow-mindedness" (DWB 11/1873, column 1131).

As a term in German statistics, Kleinstadt first came about in the 1870s. At that time, an "increasingly positivist" definition (Matzerath, 1985, p. 241) of "the urban" had become necessary as the traditional legal concept of the town was fading away with the fundamental societal changes in the course of industrialization and political turmoil. When documenting the results of the 1875 population census, the German Statistics Agency in 1877 for the first time applied the same size range as used today (Matzerath, 1985, p. 246): The smallest urban form was designated as a range of 5,000 to 20,000 inhabitants and called Kleinstadt, and towns bigger than that but with less than 100,000 inhabitants (Großstadt) were called Mittelstadt. From the census documentation (Anonymous, 1877, p. 36) it becomes obvious that at least in this statistical context, all these settlement types were considered as mere categories of size without any further features. This "invention" of urban types can be seen as an endeavour to structure and sort the bulk of data of this second census of the newly founded (1871) German Empire besides individual, household-based or territorial ones. The same size categories with their corresponding names are still relevant in Germany today (BBSR, 2012, p. 12; see also Table 1) and they are, for example, also used in Poland (see also the papers by Konecka-Szydłowska and by Czapiewski et al. in this issue).

When claiming that population size matters only in relative terms, one must therefore not forget that there are still powerful discourses where numbers and not qualitative features create structural reality. For example, the well-known urban-rural dichotomy of the United Nations is based upon national definitions of what is to be called "urban" or non-urban (thus, in the residual logic applied: rural; UN DESA, 2015). Interestingly, most countries in Europe $(n=17)$ set a population limit. The minimum quantity of urbanity as defined in this context ranges from 200 inhabitants in Denmark to 20,000 in The Netherlands. In a second group of European countries ( $n=16$; such as Hungary or Serbia) the settlements officially designated as urban form the basis of the urban-rural dichotomy. Germany applies a population density criterion. The remaining countries (Austria, France, Romania, Slovenia and Sweden) use functional and/or more complex socio-demographic and economic definitions, for example the maximum distance between individual houses (authors' compilation based on UN DESA, 2015). 
Interestingly, both the Czech and the German cases make obvious that the definitions applied for the UN statistics and the national definitions deviate from each other: For the UN statistics, all municipalities in the Czech Republic with 2,000 inhabitants or more are called "urban". Yet, as a rule in the Czech Republic, a municipality with more than 3,000 inhabitants can be declared a town by the president of the House of Commons after the expression of the Government - or if the community substantiates that it was legally a town in the past. Because such a definition is not applicable in reality, often municipalities with more than 2,000 inhabitants could be intuitively classified as towns. However, even in the small Czechia, there are inter-regional differences: For example, the statistics in the South Moravian Region consider municipalities with 4,000 inhabitants and more as towns under the presupposition that they have a legal town status. As for Germany, in the UN statistics regions with a population density equal to or greater than 150 inhabitants per square kilometre are called "urban". Within the country, however, a more sophisticated, mixed statistical-functional definition is applied and distinguishes four basic types of settlements (Table 1). These are, by and large, still oriented on the 1887 population limits but also take centrality functions into account. According to this definition, about thirty percent of the German population lives in small towns with 5,000 to 20,000 inhabitants and/or an official function as a "central place" (i.e., usually a Grundzentrum which is the lowest rank of the German planning hierarchy). A comparison in time is not meaningful as some states (Länder) in Germany have undertaken major administrative reforms in the past years. These numbers reveal little about the concrete settlement structures and nothing about the social realities of the inhabitants. The second and third columns of Table 1, that distinguish between the number of municipalities and that of local authorities associations (Gemeindeverbände), give a slight hint of the realities behind the numbers: almost 4,500 individual municipalities form 2,100 associated small towns. The maximum number of associated communities is 49 , and even this figure greatly underestimates the quantitative numbers of districts and villages that administratively belong to small towns today. In some regions (for example, in Saxony-Anhalt), a strong tendency toward a ruralisation of small towns can be observed (Steinführer, 2016). In the course of administrative reforms at the local level, small towns particularly grow significantly in territory and incorporate surrounding villages, while thus also transforming their social structure and demographically thinning out.

Tab 1. Germany - basic data on the settlements and their administrative structure (as of 2013).

\begin{tabular}{|c|c|c|c|c|c|}
\hline & $\begin{array}{c}\text { Number of } \\
\text { municipalities }\end{array}$ & $\begin{array}{l}\text { Number of local } \\
\text { authorities }\end{array}$ & $\begin{array}{l}\text { Population } \\
\text { in } 1,000\end{array}$ & Population & $\begin{array}{l}\text { Surface } \\
\text { area }\end{array}$ \\
\hline & & $\begin{array}{c}\text { associations } \\
\text { (Gemeindeverbände) }\end{array}$ & & \multicolumn{2}{|c|}{ in per cent } \\
\hline Cities & 76 & 76 & $25,031.4$ & 31.0 & 3.7 \\
\hline Medium-sized towns & 772 & 603 & $22,917.8$ & 28.4 & 15.3 \\
\hline Small towns & 4,480 & 2,105 & $23,889.8$ & 29.6 & 44.9 \\
\hline $\begin{array}{l}\text { Rural communities } \\
\text { (Landgemeinden) }\end{array}$ & 5,907 & 1,783 & $8,928.4$ & 11.1 & 36.1 \\
\hline Sum & 11,235 & 4,567 & $80,767.4$ & 100.0 & 100.0 \\
\hline
\end{tabular}

Source: BBSR, 2016

In the Czech Republic, the role of small towns (as measured by the population development) has increased between 1991 and 2015 (Table 2). Additionally, it follows from the data that small towns are at the same time the most populated group of Czech settlements. The reason could consist in the traditionally weak position of big cities, the decreased power of medium-sized towns and the rural character of the southern part of Czechia. 
Tab 2. Czech Republic - shares of population in individual size categories of municipalities [\%].

\begin{tabular}{|l|c|c|c|c|}
\hline & $\begin{array}{c}\text { Less than } 2,000 \\
\text { inhabitants }\end{array}$ & $\begin{array}{c}2,000-<20,000 \\
\text { inhabitants }\end{array}$ & $\begin{array}{c}20,000-<100,000 \\
\text { inhabitants }\end{array}$ & $\begin{array}{c}100,000 \text { and } \\
\text { more inhabitants }\end{array}$ \\
\hline 1991 & 24.7 & 28.8 & 23.1 & 23.4 \\
\hline 2001 & 26.1 & 29.2 & 23.9 & 20.7 \\
\hline 2011 & 26.8 & 29.9 & 22.4 & 20.8 \\
\hline 2015 & 27.0 & 30.3 & 19.1 & 21.9 \\
\hline
\end{tabular}

Source: Czech Statistical Office Prague, own calculation

Whether relative or absolute size, quantitative criteria are rarely sufficient to characterise small towns. Neither a maximum nor a minimum number can be set. For example, the smallest town in Germany (Arnis) has less than 300 inhabitants while the population number of its Polish counterpart (Wyśmierzyce) is below 1,000. Yet, size - or in the case of small towns rather: smallness - matters, at least in relative terms. But the subject under investigation deserves more conceptual attention.

\section{Beyond population numbers: structural features of small towns}

Interestingly, urban studies typically focus on only three dimensions of Wirth's sociological definition of the city, that is, size, density and heterogeneity. This perception (exemplarily: Paddison, 2001, p. 5) is due to Wirth's own conceptualisation: While in the beginning of his essay defining four structural features of the city, in the main part of the paper, he restricted his attention to only three. The missing one, permanency of settlement is, however, highly relevant when studying smaller towns. In many parts of Europe, today's small towns are clearly recognisable as urban entities with an often century-long history which is first of all mirrored by their built structures. The town hall, the market square, the remains of the urban wall or a promenade (and ring road, respectively) around the town centre - these are typical signs of urbanity in rural surroundings (Hannemann, 2004, p. 21). These physical structures provide built evidence of the borough or municipal rights granted to these settlements by an emperor, often in the Middle Ages or early modern period. Across Europe, the historic charter to hold a fair or a market is still present in alternative names for small towns or for localities with at least some urban qualities, such as market towns in the U.K., bourg in France, Flecken and Markt in Germany or městys in the Czech Republic. Thus also in an immaterial sense, urbanity is present in small towns. Some contributions in this Special Issue provide evidence that being an urban place until today is of historic significance, be it with regard to current place-making strategies (in which Csurgó and Megyesi are interested), the genius loci (that is relevant to Vaishar et al.) or a tendency of "municipalisation" in Poland in recent years (described by Konecka-Szydłowska) relating to the restitution of municipal rights to settlement units that had once lost the status of a town (for the phenomenon of the so-called "new towns" in Poland see Sokołowski 2014).

No clear picture emerges in economic terms. Many small towns in Central and Western Europe have a century-long non-agrarian i.e., urban history with a local bourgeoisie, a diversified economy and a developed division of labour. Historically, small towns were often the seats and administrative centres of local noble people, and their castles or manor houses are in many places part of the built heritage until today. In this connection, the Jewish population manifests another story of small towns. For example in Moravia in the Czech Republic, Jews who were discharged or expelled from royal (bigger) towns during the $15^{\text {th }}$ century, found their refuge in smaller towns under the protection of local noble families which profited from the entrepreneurial activities of Jews in trade, finance and later industry. In this manner, 36 Jewish communities were established in Moravian small towns before 1600. Today, the economic bases of small towns differ and range from commerce, handicraft and industry to the tertiary sector (including public administration and tourism). Other small towns are or historically were specialised mining towns, spa or residential towns of rural-to-urban commuters (the latter particularly in peri-urban areas; Mayfield et al., 2005). However, in a cross-comparative European approach, one has to underline that in some regions agriculture, forestry and fishery continue to play a decisive role for small-town economies. Concerning land use and proximity to the open landscape, small towns are often considered as 
places at the urban-rural interface (Novotný et al., in this issue) allowing for simultaneous urban and rural life styles at once (Steinführer, 2016).

In order to characterise small towns another structural feature seems to be highly relevant, that is excess importance (Christaller, 2006/1933, p. 26). This relates to a certain economic, administrative, and/or cultural relevance not only for the immediate small-town population, but also for its surroundings. The German planning system, for example, reinforces this role in most states by attributing the lowest rank of the planning hierarchy (Grundzentrum) to such municipalities (BBSR, 2012). Quite a few scholars tend to define small towns from such a functional perspective, rather than based upon size (in this issue, see the papers by Malý and by Jousseaume and Talandier). In the latter contribution, for example, population numbers are not the beginning but one result of the analysis of small towns. Such a functional perspective also highlights another more general role of small towns: They bridge metropolitan and rural areas and thus balance the national settlement system (see Filipović et al. in this issue) as well as the settlement system within a region (Hinderink and Titus, 1988; see also Malý in this issue).

Regarding traditional characteristics of settlement structure such as population size, building density, social and function differentiation or social control, a meta-analysis of the research literature at first glance confirms the impression of the small town being a residual category between "the rural" and "the urban". In comparison with the city, the small town is smaller in population and territory, it is considered as socially, socio-spatially and functionally less differentiated and characterized by stronger social control and, as part of its flipside, a high amount of social capital. Sometimes, it is also regarded as being more dependent on single persons. Inevitably, such a perspective rather highlights the deficits of small towns as 'failed' cities. On the other hand and in comparison with a village, the small town is considered to be more differentiated in social, economic and spatial terms as well as with regard to technical and social infrastructure.

But the small town needs a positive definition without reference to other types of settlement. Table 3 therefore suggests a number of such criteria by distinguishing whether they are more relevant from a scholarly perspective (analytical criteria) or from a residential perspective (lifeworld criteria) by trying to relate them to each other. These attributes should be understood in the sense of the Weberian ideal type, meaning that not every "real" small town will possess the respective property.

Tab 3. Analytical and life-world criteria of the small town.

\begin{tabular}{|l|l|}
\hline Analytical criteria & Life-world criteria \\
\hline Smallness & Reasonable/manageable size \\
\hline Persistence of historical urban fabric & Identity of being an urban dweller \\
\hline Centrality (excess importance) & Proximity to the open landscape \\
\hline Formal town status (municipal/borough rights) & $\begin{array}{l}\text { Symbolic relevance of the urban history and/or formal } \\
\text { town status (municipal/borough rights) }\end{array}$ \\
\hline $\begin{array}{l}\text { Functional specialisation (e.g., residential, spa or } \\
\text { industrial town) }\end{array}$ & $\begin{array}{l}\text { Limited amount of offers and opportunities of } \\
\text { advancement }\end{array}$ \\
\hline Specific social capital & $\begin{array}{l}\text { Social proximity } \\
\text { Safety (in contrast with perception of the city) }\end{array}$ \\
\hline High share of long-established owner occupiers & Emotional bonds to the place \\
\hline
\end{tabular}

Source: authors' compilation 
In summation, the following criteria for defining small towns can be found in the literature:

- a statistical definition as described above - see also the papers by Czapiewski et al. and by Konecka-Szydłowska in this issue, based upon the usual definition in Poland;

- a functional definition that conceptualises smallness "in terms of influence and reach" (Bell and Jayne, 2009, p. 689), an approach also to be found in this issue in the papers by Jousseaume and Talandier for France and by Csurgó and Megyesi for six Hungarian case studies in this issue;

- a mixed statistical-functional definition - such as, for example, in the paper of Vaishar et al. in this issue, who set a population limit of 15,000 inhabitants for the urban core, while not defining a minimum population as it says nothing about the functions of small towns; similarly Malý who applies the same size category but explores the service functions of small towns by using service centrality as the dependent variable in his analysis;

- a mixed statistical-legal definition, for example, in Serbia where "small town" is used to designate all urban settlements with less than 20,000 inhabitants and have this status on the grounds of statistical and legislative criteria (see the papers by Filipović et al. and by Stojanović et al.) while the contribution from Slovakia (Novotný et al.), in a similar approach, takes into account small towns between 2,000 and 5,000 inhabitants, and, finally,

- a definition based upon historic privileges (an approach particularly relevant for historians but also employed in current local place-making strategies).

\section{Small towns in Europe today: some general considerations and the contributions in this issue}

Small-town research in Europe has had two major orientations in the past two decades. On the one hand, it was characterised by a discourse on economic and demographic decline, marginalisation and peripheralisation, while partly applying a comparative perspective (e.g., Wirth et al., 2016, Leetmaa et al., 2015). Inevitably, a deficit perspective on economic, social, demographic and infrastructural questions of small-town development prevailed. This strand of research was particularly strong in eastern Germany and other post-socialist countries (Bürk, 2013, Heffner and Marszał, 2005, Hannemann, 2004; see also the literature overview in Vaishar et al. in this issue). On the other hand, scholars across Europe were interested the role of small towns in strengthening the rural economy (Mayfield et al., 2005, Vaishar and Zapletalová, 2009, Powe and Shaw, 2004), their embeddedness in national and international networks (Knox and Mayer 2012), their liveability, amenities and assets. For example, as a result of their research on small towns in peripheral areas in Denmark, Fertner et al. (2015) pointed to the fact that between 2000 and 2013 this type of settlement experienced a positive, or at least stable, population. Both in central and in peripheral regions, this was due mainly to an increased in-migration of elderly people to service towns. The authors interpret this trend as a sign for what they call "residential urbanism" which is decoupled from "job-created urbanism" (ibid., 124, 130) and which, in the era of multi-locality and a high degree of mobility by a considerable part of the population, provides an additional path of small-town futures, besides culture-based growth strategies or tertiarization (Lorentzen and van Heur, 2012).

In this vein, the contributions in this Special Issue intend to further advance the interest in smalltown research in both rural and urban studies:

- Jiři Malý, by conducting a case study in South Moravia (Czech Republic), particularly focuses on the service function of small towns in the metropolitan area of Brno, the second largest city of the Czech Republic. The question of centrality due the provision of services is discussed in light of two distinct theoretical propositions, that of "borrowed size" relating to an advantage stemming from the proximity to a city or that of "agglomeration shadow" suggesting a deficit in service functions. Empirically, a coexistence of the two processes in the case study region, as well as the importance of tourism and commercial attractiveness in particular, is revealed.

- Antonín Vaishar, Jana Zapletalová and Eva Nováková ask for the sustainability of small Czech towns and measure it in terms of its demographic, economic and social dimension by aiming at a small-town typology. The factor found to be most important, however, was the position of small towns in the settlement system with regard to the vicinity to and accessibility of regional 
centres. In conclusion the authors claim that this factor is highly relevant for small-town development in general.

- In a long-term approach, Ladislav Novotný, Stela Csachová, Marián Kulla, Janetta NestorováDická and Loránt Pregi analyse the economic and demographic development of twelve small towns in East Slovakia. For most of them, the socialist industrialisation and post-socialist transformation were the most relevant historical processes. The authors conclude that even though most of these towns faced unfavourable trajectories in the recent past due to population decline and deindustrialisation and despite of losses in functions, they are still valid nodes for their rural hinterlands.

- Valérie Jousseaume and Magali Talandier deal with the dynamics of small towns in France which are defined exclusively in terms of their commercial and service functions (with regard to education, healthcare and local supply), not according to population counts or number of jobs. The population of small French towns thus identified ranges from 6,200 to 35,500 , with 3,500 to 19,000 jobs. The authors' particular focus is on small-town population dynamics. In recent years, quite exceptionally in the European context, rural areas in France witnessed a demographic renewal, not least also due to secondary and holiday residences. In southern and western France, small towns play a key role in this, as Jousseaume and Talandier call it, "residential economy".

- By taking the example of the Mazovia region in Poland, Konrad Czapiewski, Jerzy Bański and Magdalena Górczyńska compare a number of small towns according to their importance and functional diversity. Both features increase with the growing distance from the metropolitan centre (Warsaw). According to the authors' findings, the role of more distant small towns is greater than their demographic and economic potentials suggest. Indeed, these urban centres play a regionally limited, yet important, socio-economic role with regard to adjacent rural areas in terms of services, trade, transport, production, administration and secondary education, but also local labour markets.

- Bernadett Csurgó and Boldizsár Megyesi take the example of six Hungarian rural microregions to analyse how rural small towns position themselves in local place-making. They find that the characteristics and territorial scope of the local cultural heritage significantly determine the innovative capacity of small towns in local image building while there is a wide range of meanings, procedures and processes of place-making. The authors identify three types of place-making: the monopolistic model in which the central town defines the symbol, the inclusive model in which actors aim at reaching a consensus about the symbol and at cooperating in the symbolization process, and, finally, a mixed third type where the character of the symbol seems to be less influential on the symbolization process.

- The significance of small towns in the urbanisation process of the Wielkopolska region in Poland is in the focus of the contribution by Barbara Konecka-Szydłowska. The author takes into account the demographic and the spatial dimension of urbanisation. A characteristic feature of the population change taking place in Polish agglomerations is the depopulation of the respective core city (that is in Wielkopolska Poznań) accompanied by suburban growth. Also, a number of suburban small towns increase in population numbers. Wielkopolska region is characterised by a great number of mostly small towns, the population of which is, however, relatively stable in comparison with other Polish regions.

- Small towns are considered as a "bridge" between urban and rural life worlds in Serbia by Marko Filipović, Vlasta Kokotović Kanazir and Marija Drobnjaković. Small towns, defined based on population quantity and legislative criteria make up 75 per cent of all urban settlements in Serbia. This share has increased in the past decades as a number of settlements were granted the administrative status of a town. Yet, concerning size, functionality and centrality, the authors argue that the current distinction between urban and rural settlements in Serbia does not correspond to the reality. Their analysis of the demographic conditions of Serbian small towns reveals that these are better than the national average. Small towns, whether in the vicinity of major urban centres or as central places in rural environments, reduce the degree of the spatial and functional periphery of rural areas and enable rural residents an easier access to basic functions. 
- The final paper of this Special Issue, a small communication by Jasna Stojanović, Vlasta Kokotović Kanazir and Maja Stojanović, analyses the tourism potential of small towns in Serbia and their demographic development. The authors find that the towns under investigation have a more favourable demographic pathway compared to other small towns. In some of them, tourism even contributed to population increase and a transformation of the local employment structure.

\section{Going beyond structural deficits and strong social capital: future tasks for small-town research}

Based upon the considerations in this short introduction and the contributions in this Special Issue, a clear message comes about, that is: social scientists need to go beyond the two-fold perspective of small(er) towns as being "specific" types of urbanity. One of the two poles is the misleading approach towards this type of urban settlement as apparent incarnation of modernity deficits. This is a long-standing cliché, reaching back to the early days of urban (rather: metropolitan) sociology (for Germany, by using the example of Georg Simmel, see Steinführer, 2016). Yet, the second perspective that highlights the somewhat "cosy" nature of small towns, while time and again highlighting their specific social capital and personal bonds (implicitly or explicitly), and, in doing so, contrasting the small town with "the" city (which, however, is usually not analysed by way of comparison) is problematic, too. While social capital and personal relationships certainly deserve scientific attention, small towns (just like rural areas) need to be thought of much more in terms of society rather than being restricted to community.

The small town belongs to the European urban heritage and is, at the same time, an indispensable part of rural areas. This double role is also reflected in its ambiguous structure allowing for both rural and urban studies to deal with it. According to Knox and Mayer (2009, p. 142), about onefifth of the European population live in small towns - and from numerous surveys it is well known that this type of settlement represents a favoured and attractive type of residence to a relevant portion of the population. Therefore, small towns need more systematic scientific attention from a multitude of disciplines, theoretical approaches and regional perspectives.

References

[1] Anonymous (1877). Die Volkszählung im Deutschen Reiche vom 1. Dezember 1875. Erster Theil. Monatshefte zur Statistik des Deutschen Reichs 25(7), 1-117.

[2] BBSR [Bundesinstitut für Bau-, Stadt- und Raumforschung] (ed.) (2012). Klein- und Mittelstädte in Deutschland - eine Bestandsaufnahme. Stuttgart: Steiner (Analysen Bau.Stadt.Raum; 10).

[3] BBSR [Bundesinstitut für Bau-, Stadt- und Raumforschung] (2016). Stadt- und Gemeindetyp. Dataset, online available:

http://www.bbsr.bund.de/nn_1086478/BBSR/DE/Raumbeobachtung/Downloads/downloads Referenz2.html (accessed: 03.03.2016).

[4] Bell, D. \& Jayne, M. (2009). Small cities? Towards a research agenda. International Journal of Urban and Regional Research 33(3), 683-699.

[5] Benke, C. (2001). Kleinstädte in Brandenburg und Mecklenburg-Vorpommern. Historische Entwicklungslinien eines Stadttyps vom Mittelalter bis zur DDR. Berlin: Humboldt-Universität (Stadt- und Regionalsoziologie, Working Paper), online: http://www.carstenbenke.de/resources/Carsten+Benke+Kleinstaedte.pdf (accessed: 4.11.2016).

[6] Besser, T. L. (2009). Changes in small town social capital and civic engagement. Journal of Rural Studies 25(2), 185-193.

[7] Burdack, J. (2010). Lokal basierte Kleinstadtentwicklung im östlichen Europa: Potenziale, Probleme und Praktiken - eine Einführung. In: Borsig, A., Burdack, J., Knappe, E., eds.: 
Small towns in Eastern Europe: local networks and urban development (pp. 5-12). Leipzig: Leibniz-Institut für Länderkunde.

[8] Bürk, T. (2013). Voices from the Margin. The Stigmatization Process as an Effect of SocioSpatial Peripheralization in Small-Town Germany. In Fischer-Tahir, A. \& Naumann, M., eds.: Peripheralization. The Making of Spatial Dependencies and Social Injustice (pp. 168-186). Wiesbaden: Springer VS.

[9] Christaller, W. (2006/1933). Die zentralen Orte in Süddeutschland. Darmstadt: WBG.

[10] DWB 9 [Deutsches Wörterbuch by Jacob Grimm and Wilhelm Grimm, Vol. 9] (1935). Greander - Gymnastik, online: http://dwb.uni-trier.de/de/ (accessed: 15.11.2016).

[11] DWB 11 [Deutsches Wörterbuch by Jacob Grimm and Wilhelm Grimm, Vol. 11] (1873). Online: http://dwb.uni-trier.de/de/ (accessed: 15.11.2016).

[12] Fertner, C., Groth, N. B., Herslund, L. B. \& Carstensen, T. A. (2015). Small towns resisting urban decay through residential attractiveness. Findings from Denmark. Geografisk Tidsskrift 115(2), 119-132.

[13] Hannemann, C. (2004). Marginalisierte Städte. Probleme, Differenzierungen und Chancen ostdeutscher Kleinstädte im Schrumpfungsprozess. Berlin: BWV Berliner WissenschaftsVerlag.

[14] Heffner, K. \& Marszał, T., eds. (2005). Problemy rozwoju małych miast w wymiarze lokalnym i regionalnym. Warszawa: Komitet przestrzennego zagospodarowania kraju PAN.

[15] Hinderink, J. \& Titus, M. (1988). Paradigms of regional development and the role of small centres. Development and Change 19(3), 401-425.

[16] Knox, P. L. \& Mayer, H. (2012). Europe's internal periphery: Small towns in the context of reflexive polycentricity. In: Lorentzen, A. \& van Heur, B., eds.: Cultural Political Economy of Small Cities (pp. 142-157). London, New York: Routledge.

[17] Körösi, J. (1887). Propositions pour arriver à une comparabilité internationale des ouvrages de recensement. Bulletin de l'Institut International de Statistique 2, 200-224, online: http://gallica.bnf.fr/ark:/12148/bpt6k615464.item.langEN (last access: 14.11.2016).

[18] Leetmaa, K., Kriszan, A., Nuga, M. \& Burdack, J. (2015). Strategies to Cope with Shrinkage in the Lower End of the Urban Hierarchy in Estonia and Central Germany. European Planning Studies 23(1), 147-165.

[19] Lorentzen, A. \& van Heur, B., eds. (2012). Cultural political economy of small cities. Milton Park: Routledge.

[20] Mattson, G. A. (1997). Redefining the American Small Town: Community Governance. Journal of Rural Studies 13(1), 121-130.

[21] Matzerath, H. (1985). Urbanisierung in Preußen 1815 - 1914. Schriften des Deutschen Instituts für Urbanistik 72. Stuttgart et al.: Kohlhammer, Deutscher Gemeindeverlag.

[22] Mayfield, L., Courtney, P., Tranter, R. \& Jones, P. (2005). The role of small and mediumsized towns in rural development. Final report - appendixes. Marketowns - Deliverable 19. Reading.

[23] Miner, H. (1952). The folk-urban continuum. American Sociological Review 17, 529-537.

[24] Paddison, R. (2001). Studying Cities. In. Paddison, R., ed.: Handbook of Urban Studies (pp. 1-9). London et al.: Sage.

[25] Powe, N. A. \& Shaw, T. (2004). Exploring the current and future role of market towns in servicing their hinterlands: a case study of Alnwick in the North East of England, Journal of Rural Studies, 20(4), 405-418.

[26] Sokołowski, D. (2014). New towns in Poland. Bulletin of Geography, Socio-Economic Series 23, 149-160. 
[27] Steinführer, A. (2016). Living in a Small Town: An Urban and a Rural Experience at Once. In: Carlow, V. M. (ed.): Ruralism. The Future of Villages and Small Towns in an Urbanizing World (pp. 40-55). Berlin: Jovis.

[28] Trávníček, F. (1936). Maloměsto a malé město. Slovo a slovesnost 2(1), 21-25.

[29] UN DESA [United Nations Department of Economic and Social Affairs] (2015). World Urbanization Prospects. The 2014 Revision. CD ROM edition: Sources for Urban Population, online: http://esa.un.org/unpd/wup/CD-ROM/WUP2014_DOCUMENTATION/WUP2014DataSource-UrbanPopulation.xls (last access: 15.11.2016).

[30] Vaishar, A. \& Zapletalová, J. (2009). Small towns as centres of rural microregions. European Countryside 1(2), 70-81. DOI: 10.2478/v10091-009-0006-4.

[31] Wirth, L. (1938): Urbanism as a way of life. American Journal of Sociology 44(1), 1-24.

[32] Wirth, P., Elis, V., Müller, B. \& Yamamoto, K. (2016). Peripheralisation of small towns in Germany and Japan - dealing with economic decline and population loss. Journal of Rural Studies 47(1), 62-75. 